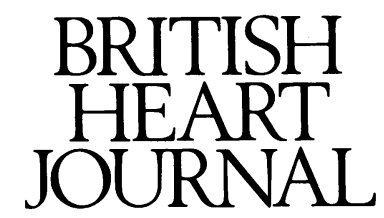

\title{
Extending the use of autologous arterial conduits in myocardial revascularisation
}

\begin{abstract}
Anastomosis of the left internal mammary artery to the left anterior descending coronary artery gives excellent longterm patency and improved early and late survival with few myocardial infarctions and reoperations..$^{1-3}$ The advantages of using the internal mammary artery operate irrespective of age, sex, degree of left ventricular dysfunction, pattern of coronary disease, and surgical caseload. ${ }^{45}$ The apparent benefits of a single internal mammary artery graft made it both inevitable and appropriate that more extensive use of autologous arterial conduits should be evaluated to determine whether it would result in additional improvements in late morbidity and mortality. Use of both internal mammary arteries for grafts, including free and sequential grafts, has been the most commonly applied technique. ${ }^{67}$ The right gastroepiploic ${ }^{8}$ and inferior epigastric arteries ${ }^{9}$ have also been used successfully. So far large groups of patients with these alternative conduits have not been evaluated.
\end{abstract}

The case for the more widespread application of multiple autologous arterial grafts can be considered in three broad areas: ( $a$ ) operative technical factors; $(b)$ early morbidity and mortality; and $(c)$ late survival of grafts and patients, cardiac events, and freedom from reoperation. If both internal mammary arteries are used, with sequential anastomoses and free grafts ${ }^{111}$ and lengthening procedures where necessary, ${ }^{12}$ multiple distal coronary anastomoses may be fashioned to virtually any point in the coronary system. ${ }^{13}$ However, these procedures are technically more demanding and require longer operating times than do single internal mammary artery grafts. ${ }^{57}$

The rate of early re-exploration for haemorrhage tended to be increased in the learning period; ${ }^{14}$ however, experience and attention to particular aspects of haemostasis reduced this problem. ${ }^{515}$ The reported association between sternal wound complications and bilateral internal mammary grafting is a major cause of concern. ${ }^{16-18}$ Kouchoukos et al reported infection rates of $1.9 \%$ and $6.9 \%$ for single and double mammary grafts respectively. ${ }^{17}$ In a prospective study, Grossi et al reported similar results. ${ }^{18}$ These data contrast with the series from the Cleveland Clinic in which the infection rate was $1 \%$ in patients with vein grafts, $0.9 \%$ in patients with a single mammary artery graft, and $1.7 \%$ when bilateral mammary artery grafts were used. ${ }^{19}$ In all these studies, ${ }^{16-19}$ however, there was a significant increase in the infection rate in diabetic patients given bilateral mammary artery grafts. It seems possible that the problems of increased pleuropulmonary morbidity, ${ }^{20}$ chest wall pain, ${ }^{21}$ shoulder girdle pain, ${ }^{22}$ and brachial plexus injury ${ }^{23}$ reported with single mammary artery grafting may increase with widespread use of both mammary arteries.
Because the early mortality for coronary artery surgery is low $(2-3 \%),{ }^{24}$ it is not surprising that the addition of multiple internal mammary artery grafts did not improve survival. ${ }^{725}$ More noteworthy is that despite the increased complexity of such operations there was no detrimental effect on early survival. ${ }^{725}$ The possible late benefits of bilateral internal mammary grafts remains to be established. ${ }^{3710}$ A prospective trial to compare multiple mammary artery grafting with a single left internal mammary artery to the left anterior descending coronary artery and additional saphenous vein grafts showed no difference in survival at four years. ${ }^{7}$ However, in observational studies with a $10-15$ year follow up patients with bilateral internal mammary artery grafting had a survival advantage and fewer late cardiac events and reoperations. ${ }^{26}$ Though these studies may be criticised because of their selection bias and the relatively small numbers, it is nevertheless difficult to ignore these apparent benefits.

The long-term follow up data from the Cleveland Clinic group, whose previous work had such a profound effect on surgical practice worldwide, will be of great interest. Why is the internal mammary artery protected from intimal thickening before as well as after it is used as a bypass graft? Should we expect the same freedom from degeneration and late occlusion in other arterial conduits? The mammary artery has a denser internal elastic lamina that is almost perfectly formed at an early age. ${ }^{27}$ It does not show evidence of discontinuities containing smooth muscle cells from the media. ${ }^{27}$ The media is primarily elastic with scanty smooth muscle cells. ${ }^{28}$ Occasional intimal thickening is seen but this usually consists of matrix covered by endothelium. ${ }^{27}$ It has been postulated that an internal elastic lamina with no fenestrations can suppress intimal thickening. ${ }^{27}$ This may be the basic reason for the longevity of the mammary artery graft. In contrast the internal elastic lamina of the gastroepiploic and the inferior epigastric arteries show fenestrations and the media is rich in smooth muscle cells and relatively poor in elastin. ${ }^{28}$ There are fewer discontinuities, however, than in the saphenous vein, which suggests an intermediate tendency for intimal thickening to develop. ${ }^{27} 28$

The low incidence of atherosclerosis in the mammary artery is probably related to its ability to release vasoactive substances ${ }^{29} 30$ capable of protecting the vascular wall from platelet adhesion and aggregation and from vasospasm. ${ }^{31} 32$ Concentrations of prostacyclin ${ }^{29}$ and endothelium derived relaxing factor ${ }^{30}$ are higher in the mammary artery than in the saphenous vein. The endothelium of the gastroepiploic artery also secreted more of these vasodilators and inhibitors of platelet activity. ${ }^{334}$ This may indicate the strong likelihood of an acceptable long-term patency rate 
for this conduit. There is no information on the biochemical properties of the inferior epigastric arteries.

Advocates of the use of the right gastroepiploic and inferior epigastric arteries showed that these conduits can be used with good early results and minimal increases in operating time and morbidity. ${ }^{89}$ Though some reservations about a more liberal use of these alternative conduits are warranted their role in routine myocardial revascularisation merits further evaluation. When other autologous conduits are scarce they may prove invaluable.

In 1989 in the United Kingdom less than $4 \%$ of patients undergoing myocardial revascularisation had bilateral internal mammary artery grafting whereas $60 \%$ had single internal -mammary artery grafting. ${ }^{23}$ No information is available on the use of the gastroepiploic and inferior epigastric arteries. Widespread use of arterial conduits depends on the long-term survival and freedom from angina and reoperation after their use. This information can only be obtained by careful audit of surgical results and appropriate clinical trials. This may provide the necessary stimulus to surgeons and hospitals to accept the increased complexity, operation time, and surgical expertise required to extend the use of autologous arterial conduits in myocardial revascularisation.

GIANNI D ANGELINI

Department of Cardiac Surgery,

University of Sheffield,

Northern General Hospital,

Sheffield S5 $7 A U$

Department of Cardiac Surgery,

ALAN J BRYAN

University of Wales College of Medicine,

Cardiff CF4 4XN

1 Loop FD, Lytle BW, Cosgrove DM, et al. Influence of the internal mammary graft on 10 year survival and other cardiac events. N Engl J Med graft on 198 ; 1 : 6 .

2 Cameron A, Kemp Jr HG, Green GE. Bypass surgery with the internal mammary artery graft: 15 year follow up. Circulation 1986;74 (suppl III): 30-6.

3 Kirklin JW, Naftel DC, Blackstone EH, Pohost GM. Summary of a consensus concerning death and ischaemic events after coronary artery consensus concerning death and 79 (suppl I):81-91.

4 Cameron A, Davis KB, Green GE, Myers WO, Pettinger M. Clinical implications of internal mammary artery bypass grafts: the Coronary Artery Surgery Study experience. Circulation 1988;77:815-9.

5 Loop FD, Lytle BW, Cosgrove DM. New arteries for old. Circulation 1989;79(suppl I):40-5.

6 Lytle BW, Cosgrove DM, Loop FD, Barsh J, Goormastic M, Taylor PC. Perioperative risk of bilateral internal mammary grafting; analysis of 500 cases from 1971 to 1984. Circulation 1986;74(suppl III):37-52.

7 Morris JJ, Smith LR, Glower DG et al. Clinical evaluation of single versus multiple mammary artery bypass. Circulation 1990;82(suppl IV):214-23.

8 Suma H, Wanibuchi Y, Furuta S, Isshiki T, Yamaguchi T, Takanashi R. Comparative study between the gastroepiploic and the internal thoracic
artery as a coronary bypass graft. Size, flow, patency, histology. Eur $J$ Cardiothorac Surg 1991;5:244-7.
9 Barner HB, Naunheim KS, Fiore AC, Fischer V.W, Harris HH. Use of the inferior epigastric artery as a free graft for myocardial revascularisation. Ann Thorac Surg 1991;52:429-37.

10 Galbut DL, Tradd EA, Dorman MJ, et al. Seventeen year experience with bilateral internal mammary artery grafts. Ann Thorac Surg 1990;49: 195-201.

11 Rankin JS, Newman GE, Bashore TM, et al. Clinical and angiographic assessment of complex mammary artery bypass grafting. $J$ Thorac assessment of complex mammary
Cardiovasc Surg 1986;92:832-46.

12 Cosgrove DM, Loop FD. Techniques to maximize mammary artery length Ann Thorac Surg 1985;40:78-9.

13 Vander Salm TJ, Chowdhary S, Okike ON, Pezzella AT, Pasque MK. Internal mammary artery grafts: the shortest route to the coronary arteries. Ann Thorac Surg 1989;47:421-7.

14 Lytle BW, Cosgrove DH, Saltus GL, Taylor PC, Loop FD. Multiple coronary revascularisation without saphenous vein: long term results of bilateral internal mammary grafting. Ann Thorac Surg 1983;36:540-7.

15 Green GE. Use of internal thoracic artery for coronary artery grafting. Circulation 1989;79(suppl I):30-3.

16 Hazelrigg SR, Wellons HA Jr, Schneider JA, Kolm P. Wound complications after median sternotomy; relationship to internal mammary grafting. $J$ Thorac Cardiovasc Surg 1989;98:1096-9.

17 Kouchoukos NT, Wareing TH, Murphy SF, Pelate C, Marshall WG Jr. Risks of bilateral internal mammary artery bypass grafting. Ann Thorac Surg 1990;49:210-9.

18 Grossi EA, Esposito R, Harris LJ, et al. Sternal wound infections and use of internal mammary artery grafts. J Thorac Cardiovasc Surg 1991;102: 342-7.

19 Loop FD, Lytle BW, Cosgrove DM, et al. Sternal wound complications after isolated coronary artery bypass grafting; early and late mortality, morbidity and cost of care. Ann Thorac Surg 1990;49:179-87.

20 Hurlbut D, Myers ML, Lefcoe M, Goldback M. Pleuropulmonary morbidity: Internal thoracic artery versus saphenous vein graft. Ann Thorac bidity: Internal thoracic

21 Eng J, Wells FC. Morbidity following coronary artery revascularisation with the internal mammary artery. Int J Cardiol 1991;30:55-9.

22 Watts $R$, Davies $R$, Treasure $T$. Internal mammary grafting increases the incidence of shoulder girdle pain after cardiac surgery. Br Heart $\mathrm{J}$ 1988;59:105-6.

23 Vahl CF, Carl I, Muller-Vahl H, Struck E. Brachial plexus injury after cardiac surgery. J Thorac Cardiovasc Surg 1991;102:724-9.

24 United Kingdom Cardiac Surgical Register, Society of Cardiothoracic Surgeons of Great Britain and Ireland. 1989.

25 Cosgrove DM, Lytle BW, Loop FD, et al. Does bilateral internal mammary artery grafting increase surgical risk. J Thorac Cardiovasc Surg 1988;95:850-6.

26 Fiore AC, Naunheim KS, Dean P, Kaiser GC, Pennington ES, Willman VL, et al. Results of internal thoracic artery grafting over 15 years: single versus double grafts. Ann Thorac Surg 1990;49:202-9.

27 Sims FH. The internal mammary artery as a bypass graft. Ann Thorac Surg 1987;44:2-3.

28 vanSon JAM, Smedts F, Vincent JG, Van Lier HJJ, Kubat K. Comparative anatomic studies of various arterial conduits for myocardial revascularisaanatomic studies of various arterial conduits for

29 Chaikhouni A, Crawford FA, Kochel PJ, et al. Human internal mammary artery produced more prostacyclin than saphenous vein. $J$ Thorac artery produced more prostacyc
Cardiovasc Surg 1986;92:88-91.

30 Luscher TF, Diedrich D, Siebenmann R, et al. Difference between endothelium dependent relaxation in arterial and in venous coronary bypass grafts. N Engl J Med 1988;319:462-7.

31 Furchgott RF, Zavadzk JV. The obligatory role of endothelial cells in the relaxation of arterial smooth muscle by acetylcholine. Nature 1980; 299:373-6.

32 Radomski MW, Palmer RMJ, Moncada S. The antiaggregating property of vascular endothelium: interaction between prostacyclin and nitric oxide. Br J Pharmacol 1987;92:639-46.

33 O'Neil GS, Chester AH, Allen SP, et al. Endothelial function of human gastroepiploic artery. Implications of its use as a bypass graft. $J$ Thorac Cardiovasc Surg 1991;102:561-5.

34 Oku T, Yamane S, Suma H, et al. Comparison of prostacyclin production of human gastroepiploic artery and saphenous vein. Ann Thorac Surg 1990;49:767-70. 